\title{
PENERAPAN REWARD AND PUNISHMENT TERHADAP PEMBENTUKAN AKHLAK DI MADRASAH IBTIDAIYAH ASIH PUTERA KOTA CIMAHI
}

\author{
Nusi Nusantari \\ Alumni Magister Pendidikan Islam Pascasarjana Unisba \\ (Guru Pendidikan Agama Islam di SMP Negeri 4 Cimahi Kota Cimahi) \\ e-mail : lusi.nusantari01@gmail.com
}

\begin{abstract}
Abstrak. Penelitian ini dilatarbelakangi oleh kurangnya pemahaman guru tentang reward and punishment yang diterapkan di Madrasah Ibtidaiyah Asih Putera Kota Cimahi terhadap pembentukan akhlak. Reward and Punishment diterapkan sebagai alat pendidikan yang membantu memberikan motivasi siswa dalam melakukan hal yang baik dan memberikan efek jera terhadap tingkah laku yang melanggar aturan. Penerapan Reward and Punishment bukan untuk sekedar menyenangkan anak atau untuk balas dendam tetapi untuk membimbing akhlak anak kearah yang lebih baik. Rumusan masalah penelitian ini : 1) Bagaimana penerapan Reward and Punishment terhadap pembentukan akhlak di Madrasah Ibtidaiyah Asih Putera Kota Cimahi ?, 2) Apa saja faktor yang mempengaruhi diterapkannya Reward and Punishment terhadap pembentukan akhlak di Madrasah Ibtidaiyah Asih Putera Kota Cimahi ? Penelitian ini bertujuan untuk mengetahui : 1) Penerapan Reward and Punishment terhadap pembentukan akhlak di Madrasah Ibtidaiyah Asih Putera Kota Cimahi, 2) Faktor-faktor yang mempengaruhi diterapkannya Reward and Punishment terhadap pembentukan akhlak di Madrasah Ibtidaiyah Asih Putera Kota Cimahi. Penelitian ini menggunakan jenis penelitian lapangan dengan pendekatan kualitatif. Metode penelitian yang digunakan adalah metode penelitian deskriptif. Teknik pengumpulan data menggunakan wawancara, observasi, dokumentasi dan studi pustaka. Adapun teknik pengolahan data yang digunakan adalah koleksi data, editing, interpretasi data dan penyajian data. Sedangkan analisis data menggunakan analisis deskriptif kualitatif. Berdasarkan hasil penelitian maka dapat disimpulkan Reward and Punishment yang diterapkan di Madrasah Ibtidaiyah Asih Putera Kota Cimahi, sebagai berikut : Reward berupa pujian, acungan jempol, tepuk tangan, hadiah, penghormatan dan penghargaan. Sedangkan Punishment berupa hafalan surat-surat juz amma, menulis Al-Qur'an, tugas tambahan, bersih-bersih kelas dan teguran. Adapun faktor-faktor yang mempengaruhinya yang terdiri dari faktor internal dan ekternal. Faktor internal yaitu dari dalam diri anak itu sendiri seperti kecerdasan, minat, bakat dan motivasi. Adapun faktor eksternal yaitu lingkungan sosial meliputi keluarga, sekolah dan masyarakat.
\end{abstract}

\section{Kata Kunci : Reward, Punishment dan Pembentukan Akhlak}

\begin{abstract}
This research triggered by lack of understanding about rewards and punishment applied in Asih Putera Madrasah Ibtidaiyah Cimahi on the establishment of "akhlak". Rewards and punishment applied as a means of education which help to give motivation and the effect of dissuading to in violation of the rule, not only to please a children or to revenge but also to guide attitude the children's attitude to a better direction. The Formulation of the problems are : 1) How is the application of rewards and punishment on the establishment of attitude in Asih Putera Madrasah Ibtidaiyah Cimahi?, 2) What factors affect the implementation of the rewards and punishment on the establishment of attitude in Asih Putera Madrasah Ibtidaiyah Cimahi? The aims of thr research are to know: 1) The application of rewards and punishment on the establishment of attitude in Asih Putera Madrasah Ibtidaiyah Cimahi, 2) Factors affecting the implementation of the rewards and punishment on the establishment of attitude in Asih Putera Madrasah Ibtidaiyah Cimahi. This research use he kind of research pitch with a qualitative approach. The methodology used is the methodology descriptive. The data collection using interviews, observation, documentation and the literature study. But data collection technique used is data collection, editing, interpretation data and presentation of data. While the analysis data using descriptive analysis qualitative Based on the result of research can be concluded rewards and punishment applied in Asih Putera Madrasah Ibtidaiyah Cimahi, as follows: rewards of praise, rising the thumb, applause, a gift, respect and appreciation. While punishment of rcan be given such as; to memerize Juz amma, writing the Al Quran, tasks, cleaning class and reproof. The factor that influence them are internal and external factors. The internal factor comes from the children them selves such as; intelligence, interest, talent and motivation. The external factors come from social environment include family, school and community.
\end{abstract}

Keywords: Reward, Punishment and the establishment of Morals 


\section{PENDAHULUAN}

\subsection{Latar Belakang Masalah}

Pendidikan dalam Islam banyak dikenal menggunakan istilah at-tarbiyah, attalim, at-ta'dib dan ar-riyadah. Setiap terminologi tersebut mempunyai makna yang berbeda satu sama lain, karena perbedaan teks dan konteks kalimatnya. Menurut AlNahlawy yang dikutip Ikhrom dalam Ismail,dkk (2001 : 79) pendidikan Islam merupakan sistem pendidikan untuk melatih anak didiknya sedemikian rupa sehingga dalam sikap hidup, tindakan, dan pendekatannya terhadap segala jenis pengetahuan banyak dipengaruhi oleh nilainilai spiritual dan sangat sadar akan nilai etik Islam. Hal ini sesuai dengan tuntunan ajaran Islam yang menganjurkan umatnya untuk memiliki nilai-nilai akhlaq karimah dengan merujuk pada pribadi Rasulullah SAW sebagaimana firman Allah SWT :
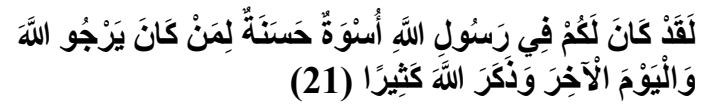

Artinya : "Sesungguhnya telah ada pada (diri) Rasulullah itu suri teladan yang baik bagimu (yaitu) bagi orang yang mengharap (rahmat) Allah dan (kedatangan) hari kiamat dan dia banyak menyebut Allah (QS AlAhzab : 21).

Kaitannya pendidikan sebagai upaya mengembangkan budi pekerti luhur, pendidikan Islam memandang bahwa pendidikan budi pekerti/akhlaq adalah jiwa pendidikan Islam. Mencapai (Marimba, 2001 ) akhlaq yang sempurna adalah tujuan sebenarnya dari pendidikan dengan akhlaq mengesampingkan aspek-aspek penting lainnya; pendidikan jasmani, akal, ilmu pengetahuan ataupun segi-segi praktis lainnya (Abrasyi, 1990 : 1). Sementara itu Iman Al-Ghazali, mengatakan bahwa akhlaq adalah hasil dari pendidikan, latihan, pembinaan dan perjuangan yang sungguhsungguh sehingga harus dibentuk. (Nata, 2007 : 154). Dan tujuan utama pendidikan Islam identic dengan tujuan hidup seorang muslim yaitu untuk menjadi hamba Allah yang percaya dan menyerahkan diri kepadaNya (Marimba, 1980 : 48).

Hal tersebut diatas sejalan dengan fungsi dan tujuan pendidikan nasional yang terkandung dalam Undang-Undang Sistem Pendidikan Nasional No. 20 tahun 2003 pasal 3 yaitu pendidikan nasional berfungsi mengembangkan kemampuan dan membentuk watak serta peradaban bangsa yang bermartabat dalam rangka mencerdaskan kehidupan bangsa, bertujuan untuk berkembangnya potensi peerta didik agar menjadi manusia yang beriman dan bertaqwa kepada Tuhan Yang Maha Esa, berakhlaq mulia, sehat, berilmu, cakap, kreatif, mandiri dan menjadi warga negara yang demokratis serta bertanggung jawab.

Proses pendidikan ini tentunya bisa dilakukan oleh pemerintah dan berbagai elemen masyarakat yang peduli pada pendidikan baik melalui jalur formal, non formal maupun in formal. Madrasah merupakan bagian integral dari jenis pendidikan dalam system pendidikan nasional dengan jenjang mulai dari pendidikan dasar (MI dan MTs) hingga pendidikan menengah (MA). Disamping itu, madrasah juga merupakan lembaga pendidikan berbasis Islam yang diharapkan mampu mempersiapkan peserta didik yang memahami dan mengamalkan nilai-nilai ajaran Islam dalam kehidupan sehari-hari.

Secara umum penyelenggaraan Pendidikan Agama Islam (PAI) disekolah atau madrasah diarahkan untuk mencapai tujuan menumbuhkan dan meningkatkan keimanan melalui pemberian pengetahuan, penghayatan dan pengamalan siswa tentang ajaran Islam sehingga menjadi manusia muslim yang berkembang kualitas keimanan dan ketaqwaannya serta memiliki akhlaq mulia dalam kehidupan pribadi dan masyarakat.

Proses pembentukan akhlaq siswa agar sesuai dengan tujuan tersebut tidak bisa hanya dengan mengandalkan proses belajar mengajar dikelas saja, tetapi perlu ada proses-proses kegiatan lanjutan yang dapat dilakukan melalui pembiasaan secara komprehensif dalam kehidupan siswa diluar 
jam belajar di kelas. Dengan kata lain upaya proses pembentukan akhlaq siswa tidak cukup hanya didekati melalui pengajaran Agama di kelas, namun harus melalui suatu kegiatan yang bersifat intregatif antara sekolah, guru, orang tua dan masyarakat dalam membina iman dan taqwa siswa baik di lingkungan sekolah, rumah dan masyarakat.

Secara legalitas formal, pemerintah telah menetapkan standar kompetensi siswa dan indicator pencapaian keberhasilannya bagi siswa pada tingkat SD/MI sebagai standar yang harus dijadikan rujukan sekolah/ lembaga/dinas terkait dalam penyelenggaraan pendidikan jenjang SD/MI.

Berdasarkan Standar Kompetensi Siswa yang ditetapkan pemerintah melalui Keputusan Menteri Pendidikan Nasional Republik Indonesia Nomor : 053/2001 tentang Pedoman Penyusunan Standar Pelayanan Minimal Penyelenggaraan Persekolahan Bidang Pendidikan Dasar dan Menengah, Siswa SD/MI diharapkan memiliki :

1) Akhlak dan budi pekerti yang luhur

2) Pengetahuan dan keterampilan dasar yang sesuai dengan kurikulum yang berlaku

3) Kesehatan dan kebugaran, apresiasi seni, dan dasar-dasar olah raga yang sesuai bakat dan minatnya

4) Kemampuan melanjutkan pendidikan ke jenjang pendidikan yang lebih tinggi

Untuk mencapai standar kompetensi tersebut, Madrasah Ibtidaiyah menyelenggarakan proses belajar mengajar yang kurikulumnya mengacu pada pencapaian tujuan dan harapan tersebut. Disamping itu, pihak madrasah melaksanakan program-program dan kegiatan yang menunjang pencapaian tujuan tersebut.

Usaha - usaha dilakukan untuk pembentukan akhlak di lembaga pendidikan melalui berbagai macam program dan metode terus berkembang. Salah satu yang dapat dilakukan oleh lembaga pendidikan adalah penerapan metode reward dan punishment dalam pembentukan akhlak terpuji bagi siswa.

Reward adalah sebagai alat untuk mendidik anak-anak supaya anak dapat merasa senang karena perbuatan atau pekerjaan yang mendapatkan penghargaan. (Ngalim 2007 : 182). Reward adalah hadiah, pembalas jasa, alat pendidikan yang diberikan kepada siswa yang telah mencapai prestasi baik. (Praja 1978:169). Dari beberapa Pengertian di atas menunjukkan bahwa ganjaran tersebut merupakan alat pendidikan yang menyenangkan dan sekaligus menjadi motivasi belajar agar lebih membiasakan diri untuk belajar dengan baik, agar dapat melakukan perbuatan terpuji dan berusaha untuk meningkatkannya.

Punishment adalah penderitaan yang diberikan atau ditimbulkan dengan sengaja oleh seseorang (orang tua, guru, siswa dsb) sesudah terjadi suatu pelanggaran, kejahatan, atau kesalahan. Punishment diberikan bukan untuk balas dendam kepada siswa melainkan memperbaiki tingkah lalu yang kurang baik kearah yang lebih baik.

Ada berbagai hadits yang berbicara mengenai pemberian reward dan punishment, salah satunya adalah sebagai berikut, yaitu :

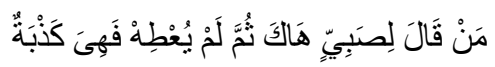

Barang siapa berkata kepada anak kecil : "kemarilah dan ambillah sesuatu", lalu ia tidak memberinya, maka perbuatan itu adalah suatu kedustaan. (HR. Ahmad)

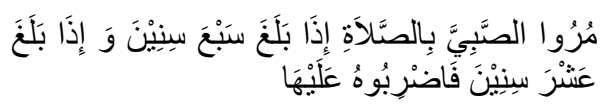

Perintahkanlah anak kecil untuk melaksanakan shalat apabila sudah mencapai umur tujuh tahun, dan apabila sudah mencapai sepuluh tahun maka pukullah dia apabila tidak melaksanakannya. (HR. Abu Dawud No. 417)

Hadits yang pertama menginstruksikan bahwa setiap tindakan positif yang dilakukan seorang anak harus diberikan reward positif, 
sedangkan hadits yang kedua menginstruksikan bahwa setiap tindakan negatif yang dilakukan anak harus diberikan punishment atau hukuman.

Reward and punishment ini merupakan salah satu metode dalam perubahan perilaku yang merupakan bagian dari aliran behavioristik. Menurut skinner respon-respon yang dihasilkan oleh organisme-organisme memiliki konsekuensi terhadap lingkungannya. Jika respons tersebut mendapat reward, respons tersebut akan lebih mungkin kembali muncul, hal ini mengindikasikan manfaat yang besar reward terhadap dunia pendidikan dalam meningkatkan motivasi, minat belajar dan perubahan akhlak. Setiap guru mengupayakan timbulnya suatu respons positif dari peserta didik, tetapi kenyataannya banyak perilaku peserta didik yang timbul tanpa diharapkan, seperti perilaku agresif, kurangnya motivasi terhadap pembelajaran dan seringnya peserta didik tidak melaksanakan tugas yang diberikan oleh guru, maka sesungguhnya ada celah penggunaan punishment walaupun sebenarnya penggunaan punishment ini tetap saja menjadi kontroversi di kalangan ahli pendidikan saat ini.

Setiap pembelajaran tidak dapat terlepas dari pemberian suatu hadiah atau ganjaran (reward) dan hukuman (punishment), reward memiliki fungsi agar peserta didik mengulangi suatu hal positif yang dilakukannya sedangkan hukuman memiliki fungsi agar peserta didik tidak mengulangi kesalahan yang diperbuatnya. Pada kenyataannya di dunia pendidikan, banyak terjadi penggunaan punishment secara berlebihan tanpa adanya kontrol dan modifikasi, sedangkan reward sendiri kurang mendapatkan perhatian, karena sifat reward yang tidak secara langsung mengoreksi sebuah perilaku secara cepat, reward akan berefek kuat apabila dilakukan secara terus menerus dan konsisten. Diakui secara umum dalam dunia pendidikan masa kini, bahwa penggunaan reward lebih baik dibandingkan penggunaan punishment dalam meningkatkan motivasi peserta didik.
Sebagian guru ada yang mengoreksi kesalahan peserta didik dengan berbagai punishment, dapat berupa hukuman verbal, psikis, bahkan dapat mempergunakan hukuman fisik. Hukuman verbal dapat berupa hinaan, cemoohan dan kritikan tajam, kemudian hukuman psikis dapat berupa pengabaian dan diskriminasi, dan hukuman fisik bisa berupa penjeweran, cubitan, melakukan olahraga fisik semisal pushup atau situp, bahkan ada yang melakukan penamparan dan yang lebih berat darinya. Sedangkan penggunaan reward, semisal pujian dan hadiah kurang mendapatkan porsi yang cukup dalam pembelajaran karena sifatnya yang "dianggap lamban" dalam merubah perilaku.

Madrasah Ibtidaiyah Asih Putera adalah Madrasah Swasta yang berada di Kota Cimahi yang sudah menerapkan Reward and Punishment disekolahnya, yang bertujuan memotivasi siswa dan membentuk akhlak siswa menjadi lebih baik.

Dalam penerapannya, guru akan memberikan sebuah reward kepada siswa yang memenuhi kriteria sebagai usaha meningkatkan pembentukan akhlak dan sikap yang baik. Dan siswa juga akan diberikan punishment sesuai dengan peraturan, jika ia tidak bisa mengaktualisasikan akhlak yang baik. Sehingga siswa bisa menerima dengan besar hati dan tidak ada kesalah pahaman antara guru dan siswa. Dan tentunya akan membawa dampak positif yang menjadikan siswa menjadi lebih baik terutama dalam hal berakhlak.

Berdasarkan permasalahan diatas, maka penulis ingin meneliti dan mengkaji lebih dalam melalui sebuah penelitian dengan judul, " Penerapan Reward and Punishment terhadap Pembentukan Akhlak di Madrasah Ibtidaiyah (MI) Asih Putera Kota Cimahi”.

\subsection{Perumusan Masalah}

Berdasarkan latar belakang di atas, permasalahan dalam penelitian ini dapat dirumuskan sebagai berikut :

1. Bagaimana penerapan reward and punishment terhadap Pembentukan 
Akhlak di Madrasah Ibtidaiyah Asih Putera Kota Cimahi ?

2. Apa saja faktor yang mempengaruhi diterapkannya reward and punishment terhadap Pembentukan Akhlak di Madrasah Ibtidaiyah Asih Putera Kota Cimahi?

\subsection{Tujuan Penelitian}

Berdasarkan perumusan masalah penelitian, maka tujuan yang hendak penulis capai adalah sebagai berikut :

1. Untuk mengetahui bagaimana penerapan reward and punishment terhadap Pembentukan Akhlak di Madrasah Ibtidaiyah Asih Putera Kota Cimahi

2. Untuk mengetahui faktor yang mempengaruhi diterapkannya reward and punishment terhadap Pembentukan Akhlak di Madrasah Ibtidaiyah Asih Putera Kota Cimahi

\section{PEMBAHASAN}

\subsection{Penerapan Proses Pembentukan}

Akhlak melalui Reward dan

Punishment di Madrasah Ibtidaiyah Asih Putera Kota Cimahi.

\section{a. Penerapan Reward}

Reward yang diterapkan oleh beberapa guru berbeda-beda dengan bebrapa cara yang berbeda pula dalam proses pembelajaran maupun di luar kelas. Sebagai berikut:

\section{1) Pujian}

Reward bentuk pujian ini bisa berupa kata-kata seperti: "kamu sangat pintar", "kamu sangat rapi pakaiannya" atau "gerakan kamu sangat bagus saat menendang bola tadi" dan kata-kata pujian lainnya. Cara yang dilakukan beberapa guru tersebut dapat membangkitkan semangat anak. Reward ini diperuntukkan bagi seluruh anak yang bersekolah di Madrasah Ibtidaiyah Asih Putera Kota Cimahi.

Mengenai waktu reward bentuk pujian ini tidak terjadwal karena dapat dilakukan kapanpun itu, ketika kita melihat anak yang sedang memungut sampah yang berserakan lalu membuangnya ke tempat sampah atau ketika anak sangat memperhatikan saat pembelajaran berlangsung. Ibu Nanih Suhartini, S. Pd menerapkan itu pada saat ada anak yang pakaian kurang rapi yang kemudian ada anak lainnya yang pakaiannya sangat rapi dan bersih sebagai contoh bagi anak yang lainnya.

Begitu pula mengenai tempat dilaksanakan dimanapun dan kapanpun reward ini tidak terlalu susah untuk menerapkannya. Di lingkungan sekolah maupun luar sekolah juga. Bapak Yudi, S. Pd. I di dalam kelas kebanyakan menerapkan reward pujian ini karena anak dapat mengerjakan soal dengan benar yang telah diberikan.

Reward bentuk pujian ini sangat mudah dilakukan oleh siapapun, kapanpun dan dimanapun berada. Tidak perlu adanya waktu khusus atau tempat khusus untuk melakukan itu, namun jangan telalu sering juga menerapkan pujian ini pada anak ditakutkan anak akan terlena dengan pujian dan lupa akan tugasnya. Ada kalanya pujian dengan motivasi yang membuat anak mau sedikit demi sedikit terdorong untuk lebih semangat belajarnya dan bertingkahlaku baik terus-menerus.

Walaupun ada juga guru yang tidak biasa menerapkan reward seperti pemberiaan hadiah, padahal secara tidak langsung senyum dan pujian yang mereka berikan kepada anak-anak itu sudah termasuk reward, namun mereka tidak menyadari itu. Padahal seharusnya dalam beberapa kali pembelajaran berlangsung sisipkan sedikit reward berupa hadiah agar respon anak terhadap gurunya dalam memberikan pelajaran lebih baik, sekalipun dalam 1 bulan cuma sekali itu akan berdampak sangat baik karena anak lebih suka kalau jerih payahnya belajar selama ini diapresiasi dengan adanya hadiah walaupun cuma satu buah pulpen atau alat yang menunjang pendidikan lainnya. 


\section{2) Acungan jempol}

Acungan jempol juga merupakan bentuk reward yang sederhana namun memberikan efek yang bagus bagi pembentukan akhlak anak. Biasanya ini dilakukan oleh Ibu Ai Cahyati, S. Pd. I setiap anak yang apalagi ketika materi pembelajaran yang mengharuskan anak berani mengemukakan pendapatnya, itu adalah hal yang sangat bagus dan biasanya dilakukan karena dengan diberi acungan jempol anak merasa dihargai dan senang. Paling tidak anak berani mengemukakan pendapatnya salah benarnya itu nanti yang penting anak mau aktif dalam pembelajaran.

Baiknya seorang guru juga mempersilahkan anak yang lainnya juga agar berani seperti temannya itu dengan dorongan semangat yang bisa membuat anak memberanikan dirinya mengemukakan pendapat. Berarti guru tersebut sudah melaksanakan dengan baik reward dalam bentuk acungan jempol ini.

\section{3) Tepuk Tangan}

Tepuk tangan adalah hal biasa yang sering kita lihat. Tetapi dalam dunia pendidikan tepuk tangan salah satu bentuk reward yang biasa dilakukan oleh guruguru di sekolah ketika dalam proese pembelajaran. Ibu Nanih Suhartini, S. Pd. menerapkannya ketika pembelajaran beliau berlangsung saat pemberian tugas kelompok, setiap kelompok yang maju pasti diberikan tepuk tangan oleh semua teman-temannya agar lebih semangat dan percaya diri ketika di depan.

Hal demikian sudah bagus dilakukan ketika proses pembelajaran dan anakpun menjadi lebih semangat dalam belajar dan menjalani kegiatan sekolah karena mendapat respon yang bagus dari guru maupun teman-temannya. Tetapi harus dikontrol juga dengan cara jangan terlalu sering dan keras ketika tepuk tangan, karena bisa mengganggu kelas yang lain ketika pembelajaran berlangsung kecuali di luar kelas tepuk tangannya baru harus keras agar merasa lebih berasa pujian yang telah diberikan dan membuktikan bahwa memang yang dilakukan anak yang mendapat reward itu baik serta patut untuk dipuji dan dihargai walau hanya dengan tepuk tangan.

\section{4) Penghormatan}

Penghormatan biasanya diberikan oleh pihak sekolah selalu dilaksanakan dalam setiap akhir semester pelajaran. Reward yang seperti ini biasanya untuk anak-anak yang nilainya baik atau juara di kelasnya dan di umumkan pada saat acara pembagian raport dan pengumuman kelulusan. Penghormatan dalam hal ini anak-anak yang nilainya bagus akan ditampilkan di depan sebagai prestasinya telah mencapai hasil yang bagus ketika proses pembelajaran. Reward ini biasanya diterapkan agar anak-anak yang lain termotivasi untuk meningkatkan prestasi mereka.

Pihak sekolah harusnya juga menyisipkan nasehat-nasehat bagi anakanak yang lain agar mau meningkatkan kegiatan dan prestasi belajarnya lebih giat lagi. Akhlak anak pun sedikit demi sedikit di arahkan menjadi lebih baik jangan sampai dibiarkan begitu saja.

\section{5) Hadiah}

Hadiah adalah suatu hal yang menggembirakan bagi siapapun yang menerimanya. Penerapan ini dilakukan secara berkala tidak setiap waktu. Hadiah diberikan bagi anak yang aktif saat pembelajaran, berprestasi dan bertingkah laku baik di luar maupun di dalam kelas.

Bentuk hadiah yang diberikan biasa berupa benda, seperti alat tulis, permen, bros dan hadiah-hadiah lainnya yang bermanfaat bagi anak. sedangkan ketika kenaikan kelas atau untuk juara kelas bisa berupa piagam dan kado yang telah dipersiapkan pihak sekolah untuknya karena berprestasi.

Hadiah seharusnya jangan terlalu sering diberikan pada proses pembelajaran berlangsung, adakalanya dilakukan pada saat-saat tertentu saja misalnya 1 bulan sekali yang penting jangan terlalu sering. Ditakutkan anak akan terbiasa kalau ingin menjawab atau melakukan aktifitas belajar 
apapun harus dengan hadiah, itu membuat mereka ketergantungan dengan hadiah tidak ada lagi keinginannya sendiri.

Hadiah yang terlalu sering diberikan juga bisa membuat anak jadi malas memperhatikan pelajarannya tetapi lebih kepada hadiahnya, dan bisa membuat anak nantinya setiap pembelajaran berlangsung di luar maupun di dalam kelas menginginkan hadiah terlebih dahulu sebelum melakukan yang telah diperintahkan gurunya. Kalau tidak diberi hadiah anak itu bisa tidak memperhatikan apa yang disampaikan gurunya. Seperti yang disampaikan Bapak Wirhasani yang tidak terlalu sering memberikan hadiah setiap beliau mengajar, karena bisa membuat anak ketagihan dan setiap belajar pasti meminta hadiah, itu pun dilakukan agar anak lebih memperhatikan pelajaran dan lebih mentaati peraturan dengan banyak memberikan nasehat pada setiap pelajaran berlangsung.

\section{6) Tanda Penghargaan}

Penghargaan diperuntukkan anakanak yang berprestasi biasanya mendapatkan reward berupa piagam dan alat tulis yang dipersiapkan oleh sekolah. Penghargaan yang diterima oleh anak bukan untuk sekedar pemberian saja tapi harus dipertahankan prestasi anak tersebut dengan tidak lepas membimbingnya baik dari segi intelektualnya maupun tingkahlakunya.

Seorang guru tidak boleh hanya sekedar melihat dan memberikan penghargaan saja. Mereka harus tetap membimbing dengan selalu memberikan nasehat-nasehat yang disisipkan pada saat pelajaran berlangung maupun di luar kelas ketika waktu senggang dengan cara yang lemah-lembut sehingga anak dengan mudah menerimanya. Adapun juara kelas pada semester 1 kelas IV B adalah Noorraisha Tiara Putri yang mendapatkan nilai tertinggi di kelasnya dan diberikan penghargaan oleh sekolah.

\section{b. Penerapan Punishment}

Punishment adalah hukuman yang diberikan untuk anak yang telah melanggar peraturan sekolah baik berupa tata tertib, kegiatan belajar mengajar, dan aktifitas yang mengganggu kegiatankegiatan di sekolah.

1) Preventif (pencegahan) Punishment yang diterapkan dengan adanya tata tertib. Tata tertib adalah langkah agar anak tidak bersikap yang aneh-aneh dan negatif. Hal tersebut sesuai dengan teori hukuman preventif yaitu hukuman yang sifatnya untuk mencegah dari perilaku anak yang kurang wajar sekaligus mencegah anak berbuat kesalahan yang lebih besar.

\section{2) Represif (kesalahan)}

Refresif yang diterapkan keepada anak contohnya tidak memakai seragam sekolah, tidak mengerjakan tugas dan, datang terlambat yaitu anak datang lebih dari waktu masuk pelajaran maka anak akan dikenakan hukuman bisa berupa hafalan surah-surah pendek atau bersihbersih. Punishment yang diterapkan demikian untuk membut anak tidak mengulanginya lagi dan merasa jera karena perbuatan salahnya itu.

Punishment yang telah diterapkan jangan sampai membuat anak merasakan kenestapaan yang mendalam, maka dari itu hendaknya ketika seorang guru memberikan punishment harus ada tindak lanjutnya, tidak hanya sekedar menerapkannya saja. Misalnya anak tersebut mendapat bimbingan belajar, lebih sering diberi nasehat agar anak tidak mengulanginya lagi.

Guru harus memperhatikan setiap anak didiknya untuk mengenali karakter masing-masing anak agar lebih memudahkan guru menerapkan punishment agar tidak keliru. Hukuman yang dilakukan pun harus sesuai dengan kesalahan yang diperbuat anak tidak sembarang hukum. Apabila anak melanggar sekali maka akan diberi teguran, yang kedua peringatan dan kalau tetap melakukan lagi maka akan akan diberi sanksi.

Semua tanggapan setuju walaupun sebenarnya pada kenyataannya mereka 
mengeluh akan adanya punishment yang diterapkan Madrasah Ibtidaiyah Asih Putera Kota Cimahi, tergantung individunya sendiri bagaimana menaggapinya dari segi positif maupun negatif. Pasti masih banyak anak-anak yang lainnya beranggapan bahwa punishment merupakan sekedar pengganti dari pelanggaran atau kesalahan yang mereka perbuat, oleh karenanya banyak anak yang masih tidak jera dengan yang sudah diberikannya punishment ini.

Berdasarkan wawancara dengan guru dan anak didiknya yaitu kelas IV B merespon dengan baik dengan adanya punishment yang diterapkan karena bersifat edukatif (mendidik) dan hukuman fisik pun yang bermanfaat bukan untuk menimbulkan penderitaan tetapi menimbulkan efek jera, malu dan insyaf akan kesalahannya.

\subsection{Faktor yang Mempengaruhi Penerapan Pembentukan Akhlak melalui Reward dan Punishment di Madrasah Ibtidaiyah Asih Putera Kota Cimahi.}

Ada beberapa faktor dalam menerapkan reward dan punishment yaitu faktor internal dan eksternal. Faktor internal bagi diri anak itu sendiri. Sedangkan faktor eksternal yaitu lingkungan sosialnya seperti keluarga, sekolah dan masyarakat.

Faktor internal ada pada diri anak itu sendiri. Kalau anak bisa menempatkan dirinya pada tempat semestinya, mudah bagi anak meradabtasi di lingkungan umum, baik sekolah maupun lingkungan luar.

\section{a. Faktor Internal}

Faktor internal adalah faktor yang ada pada diri anak itu sendiri contohnya kecerdasan, minat, bakat, dan motivasi.

\section{1) Kecerdasan/intelegensi}

Kecerdasan anak dapat dilihat dari aktifitas belajarnya ketika di dalam maupun di luar kelas. Dan anak yang seperti itu patut diberikan apresiasi berupa reward. Tapi tidak menutup kemungkinan yang pintar sekalipun bisa juga ia melakukan kesalahan tidak hanyak anak yang biasa saja melakukan kesalahan anak yang pintar pun juga.

Anak yang cerdas akan lebih semangat lagi dan menimbulkan prestasi yang lebih membanggakan. Semoga dengan adanya reward ia akan mempertahankan prestasinya dan lebih memperbaiki akhlaknya.

\section{2) Minat}

Minat ini tergantung pada anak yang melakukan hal yang memunculkan adanya reward dan punishment. Apabila minatnya positif maka keinginannya terhadap sesuatu itu berakhir positif dan sebaliknya apabila minatnya kearah yang negatif maka punishment bisa terjadi terhadap anak tersebut

Minat adalah keinginan yang besar terhadap sesuatu. Seseorang untuk mencapai apa yang diinginkannya harus melalui berbagai cara. Dalam hal pendidikan, anak yang memiliki minat yang positif pasti akan mencapainya dengan cara yang baik dan benar bukan jalan yang salah.

\section{3) Bakat}

Bakat anak adalah sesuatu yang terkadang kita tidak sadari. Jadi kaitannya dengan reward dan punishment terhadap bakat ini adalah bahwa kita sebagai pendidik harus teliti dalam menyikapi tingkah laku anak, baik anak yang diam mapun yang aktif dalam artian ketika ia bergaul dengan teman-temannya maupun berkomunikasi dengan gurunya. Ketika ada anak yang berbeda dengan temanteman yang lainnya hendaklah ada penganan khusus, agar anak tidak melakukan hal-hal yang tidak diinginkan. Terkait dengan bakat, anak yang seperti itu agar lebih terarah.

\section{4) Motivasi}

Motivasi merupakan dorongan dari dalam diri anak itu sendiri maupun dari orang lain. Agar mudah mencapai apa yang kita inginkan dengan melalui 
berbagai cara untuk mencapai hal tersebut. Terkait dengan akhlak dan prestasi anak maka adanya penerapan reward dan punishment yang diterapkan oleh Madrasah Ibtidaiyah Asih Putera Kota Cimahi.

Berdasarkan observasi yang dilakukan ternyata motivasi anak ketika mendapat reward semakin besar sedangkan anak yang mendapatkan punishment juga termotivasi untuk tidak mengulanginya lagi walaupun kenyataannya tetap mereka mengulanginya. Seharusnya di sanalah peran guru dalam membimbing anak akan terlihat.

\section{b. Faktor Eksternal}

1) Lingkungan sosial keluarga

Lingkungan yang baik bagi anak adalah keluarga yang sangat berperan dalam hal ini. Karena Keluarga juga berperan dalam hal itu karena pendidikan awal anak adalah dalam keluarga. Kalau keluarga tidak bisa atau kurang mampu membimbing anak, orangtua dapat mengarahkannya ke sekolah karena tugas sekolah adalah menjadikan anak pribadi yang berpotensi besar menjadi orang sukses dalam ilmu pengetahuan dan berakhlakul karimah yang naantinya akan melanjutkan generasi selanjutnya.

Terkait dengan akhlak anak, adanya penerapan reward dan punishmnet ini sebenarnya membantu orangtua yang mungkin kurang mampu mendidik anaknya dalam artian pendidikannya yang rendah atau faktor ekonomi keluarga itu sendiri. Jadi dengan penerapan reward dan punishmnet ini, semoga dapat mengubah pribadi anak yang kurang baik menjadi lebih baik dan yang sudah baik dapat mempertahankannya bahkan meningkatkannya lagi.

\section{2) Lingkungan sosial sekolah}

Sekolah sangat berperan dalam proses pendidikan anak. tidak hanya mengajarkan ilmu dunia saja tetapi juga ilmu akhirat unuk bekal di akhirat nanti. Sekolahpun juga menanamkan nilai-nilai dan keterampilan yang bisa membuat anak nantinya berguna di masyarakat luas. Pendidikan sekolah merupakan pendidikan formal karena adanya proses perencanaan dan pengelolaan yang jelas untuk mencapai suatu tujuan dalam pendidikan. Penerapan reward dan punishmnet merupakan suatu cara guru untuk membuat anak merasa adanya perhatian guru terhadap usaha mereka dalam sama-sama belajar untukmencapai hasil yang ingin dicapai. Adanya penerapan reward dan punishmnet ini juga sebagai cara untuk mengarahkan anak kearah yang lebih baik dan menjadi generasi masa depan yang tidak hanya bagus dalam segi kuantitas tetapi juga kualitasnya yang sangat tinggi.

3) Lingkungan sosial masyarakat Lingkungan masyarakat juga merupakan faktor karena anak setinggitingginya menuntut ilmu pasti pada akhirnya ke masyarakat juga kembalinya untuk kemaslahatan bersama. Lingkungan masyarakat bukan hanya tempat tinggal kita melainkan semua yang ada di sekitar kita. Lingkungan masyarakat yang baik adalah lingkungan masyarakat yang mendukung keberhasilan anak dalam dunia pendidikan, contohnya ketika ada kegiatan sekolah di lingkungan sekitar masyarakat mereka ikut serta membantu hingga kegiatan tersebut berakhir.

Sejatinya seorang anak itu terlahir dalam keadaan suci lagi baik. Namun tergantung pembawaan anak itu sendiri bagaimana ia menyesuaikan dirinya terhadap segala yang datang dari dalam dirinya maupun lingkungannya. Melihat kondisi anak yang berbeda-beda, maka dari itu pentingnya penerapan reward dan punishment ini dalam dunia pendidikan agar lebih mengenai bagaimana peran anak dalam dunia pendidikan ini.

Faktor eksternal dalam penerapan reward dan punishmnet saling keterkaitan antar semuanya. Dari lingkungan sosial anak bisa terpengaruh, kalau lingkungannnya baik maka baik pula anak tersebut kalau responnya terhadap lingkungan tersebut baik. Tapi kalau lingkungannya tidak baik akan dapat berdampak pula pada tingkahlaku anak, 
kalau dalam lingkungan sekolah pastilah pendidik akan mengembangkan lebih baik potensi anak ke arah yang dapat membuat anak menjadi orang yang berguna baik di sekolah, keluarga maupun lingkungan luar. Pentingnya penerapan reward dan punishment di dalam dunia pendidikan sekaligus mengarahkan akhlak anak agar terarah dan terhindar dari penyimpangan akhlak yang negatif. Pendidikan menginginkan anak didiknya menjadi orang yang baik, dari segi pengetahuan dan akhlaknya, agar seimbang antara ilmu yang didapatnya dengan implikasinya di lingkungan nantinya. Apalagi banyak faktor yang mendukung dari faktor internal dan eksternal berarti sangat baik sebenarnya reward dan punishment ini diterapkan baik di sekolah, keluarga maupun masyarakat luas. Karena setiap perbuatan kita di dunia ini akan mendapat balasan, yang baik balasannya baik yang buruk akan mendapat balasan juga sesuai dengan apa yang dilakukannya.

Penerapan reward hendaknya jangan terlalu sering seperti hadiah atau penghargaan tetapi kalau sekedar tepuk tangan, acungan jempol itu tidak masalah. Dan untuk punishment juga jangan terlalu berlebihan misalnya hukuman yang berbentuk pukulan sampai anak tidak berdaya lagi, hukuman seperti itu bukan hanya saja merusak fisik anak tetapi juga mental bagi anak yang terhukum maupun teman-temannya yang menyaksikan hukuman tersebut. Hukuman seperti itu sudah keterlaluan, tetapi kalau hukumannya yang edukatif seperti membersihkan dan merapikan buku-buku di perpustakaan tidak masalah karena dengan begitu aktifitas yang biasa tidak bermanfaat dilakukannya jadi tertinggalkan, tetapi untuk melakukan hukuman seperti itu lihat kondisi anak juga. Jadi seimbangkanlah antara keduanya agar anak tidak merasa terlalu terbebani dengan adanya punishment dan tidak terlena dengan adanya reward.

Tujuan semuanya itu adalah untuk menjadikan anak-anak yang dapat meneruskan masa depan dengan baik, bukan hanya dengan bermodalkan harta tetapi dengan dibekali ilmu pengetahuan dan akhlak yang baik maka lahirlah generasi yang sesuai dengan tujuan dari Dunia pendidikan dan harapan kita semua yaitu generasi dapat meneruskan serta mengembangkan ilmu pengetahuan Islami maupun umum dengan baik.

\section{PENUTUP}

\section{Kesimpulan}

Berdasarkan hasil penelitian yang telah dilaksanakan maka dapat diambil kesimpulan sebagai berikut :
1. Penerapan Reward and Punishment terhadap pembentukan akhlak di Madrasah Asih Putera Kota Cimahi pada siswa-siswa kelas I sampai kelas VI dilaksanakan oleh semua guru yang mengajar di Madrasah Asih Putera Kota Cimahi. Reward yang diterapkan berupa pujian, acungan jempol, tanda bintang, penghormatan, hadiah, tanda penghargaan, tepuk tangan dan simbolik lainnya. Sedangkan punishment berupa menghafal surat-surat pendek, menulis Al-Qur'an, bersih-bersih di kelas, tugas tambahan dan teguran.
2. Faktor yang mendalam diterapkannya Reward and Punishment terhadap pembentukan akhlak di Madrasah Asih Putera Kota Cimahi ada internal dan eksternal. Faktor internal yaitu dari dalam diri anak itu sendiri seperti kecerdasan (intelegenci), minat, bakat dan motivasi. Sedangkan faktor eksternal yaitu lingkungan sosial meliputi keluarga, sekolah dan masyarakat.

\section{Saran}

Berdasarkan hasil penelitian yang telah terlaksanakan tentang 
Penerapan Reward and Punishment terhadap pembentukan akhlak di Madrasah Asih Putera Kota Cimahi melalui kesempatan ini penulis ingin menyumbangkan sedikit buah pikiran atau saran-saran yang sekiranya dapat bermanfaat bagi kita semua terutama yang berada dalam dunia pendidikan.

1. Para Pendidik hendaknya selalu menerapkan Reward and Punishment dengan tidak berat sebelah, ketika memberikan hukuman juga harus memberikan alternative lain supaya siswa tidak melakukan pelanggaran lagi. Selain itu pendidik untuk lebih teliti dalam memahami Reward and Punishment yang diterapkan kepada anak.

2. Pembentukan Akhlak bagi siswa mutlak wajib dilakukan dalam rangka mencetak generasi unggul yang cerdas emosi, spiritual, yang dibutuhkan oleh dunia masa depan.

3. Seluruh komponen bangsa harus memiliki kesadaran kolektif terhadap pentingnya pemahaman dan pengamalan ajaran agama dan nilai-nilai lihur budaya ditengah-tengah era globalisasi dimana budaya asing begitu mudahnya masuk melalui media

4. Hasil dari penelitian ini penulis sadari masih belum sempurna mengingat keterbatasan kemampuan penulis penelitian sehingga memungkinkan untuk disempurnakan oleh peneliti selanjutnya.

\section{DAFTAR PUSTAKA}

Abuddin Nata. 2003.

Akhlak Tassawuf. Jakarta : PT Raja

Grafindo Persada.

Ahmad D Marimba. 1998.

Ilmu Pendidikan Islam. Jakarta : Rineka Cipta

Ahmad Tafsir. 1991.
Ilmu Pendidikan dalam persprektif Islam. Bandung : PT. Remaja Rosdakarya.

Departemen Agama RI, Al-Qur'an $\mathrm{Al}$ Karim dan Terjemah, Jakarta.

Departemen Agama RI, Panduan Kegiatan Ekstra Kurikuler Pendidikan Agama Islam. Jakarta : Depag.

Indrakusuma, Amier Daien. 1973. Pengantar Ilmu Pendidikan. Surabaya :. Usaha Nasional.

Matta, Anis. 2006. Membentuk Karakter Cara Islam. Jakarta : Al-I'tisham cet III hal 14.

Moch Ali. 1992.

Strategi Penelitian Pendidikan. Bandung: Angkasa.

Mohd Athiah Al-Abrasy.1990.

Dasar-dasar Pokok Pendidikan Islam (Attarbiyah Al-Islamiyah), Jakarta. terj. Bustami A Gani. Bulan Bintang.

Moleong, Lexy J.2011.

Metodologi Penelitian Kualitatif, Bandung: PT Remaja Rosda Karya.

Muhaimin. 2005.

Pengembangan Kurikulum Pendidikan Agama Islam di Sekolah dan di Madrasah dan di Perguruan Tinggi, PT Rajagrafindo.

Nasution. 2003.

Metode Penelitian Naturalistik Kualitatif. Bandung : Tarsito.

Nata, Abudin. 2012.

Akhlak Tasawuf. Jakarta : Rajawali Pers.

Noeng Muhajir. 2000.

Metodologi Penelitian Kualitatif. Yogyakarta : Rake Sarasin.

Purwanto, M. Ngalim. 2000. Pendidikan Teoritis dan Praktis. Bandung : Rosdakarya.

Quthb, Muhammad. 1993. Sistem Pendidikan Islam. Bandung : Al-Ma'arifat.

Ramayulis.2002.

Ilmu Pendidikan Islam, cet. 5. Jakarta : Kalam Mulia.

SastraPradja, M. 1978.

Kamus Istilah Pendidikan dan Umum. Surabaya : Usaha Nasional, hal 169. 
Sugiono. 2009.

Metodologi Penelitian Kuantitatif, Kualitatif dan R\&D. Bandung : Alfabeta.

Undang-undang RI No. 20 Tahun 2003. Sistem Pendidikan Nasional, Bandung: Faktor Media. 2003

Zakiyah Darajat dkk, 1992.

Ilmu Pendidikan Islam. Jakarta : Bumi Aksara.

\section{Fauziah Neneng. 2015.}

Pengaruh penerapan metode pembiasaan dan metode Reward and Punishment menjelang Pembelajaran Agama Islam terhadap karakter peserta didik. Bandung :

Pascasarjana Universitas Islam Negeri Bandung. 